\title{
Entrepreneurial Orientation and Innovation in Family SMEs: Unveiling the (Actual) Impact of the Board of Directors
}

\author{
Unai Arzubiaga \\ Department of Financial Economics I \\ University of the Basque Country (UPV/EHU) \\ Elcano 21, 48008 Bilbao (Spain) \\ Josip Kotlar \\ Department of Entrepreneurship, Strategy and Innovation \\ LUMS Centre for Family Business \\ Lancaster University Management School \\ Lancaster, LA1 4YX, United Kingdom \\ Alfredo De Massis \\ Free University of Bozen-Bolzano \\ Director of the Platform for Family Business Management \\ Innerhoferplatz 8 - piazzetta Innerhofer 8 \\ 39100 Bozen - Bolzano, Italy \\ and \\ Lancaster University Management School \\ Amaia Maseda \\ Department of Financial Economics I \\ University of the Basque Country (UPV/EHU) \\ Avda. Lehenadakari Agirre 83, 48015 Bilbao (Spain) \\ Txomin Iturralde \\ Department of Financial Economics I \\ University of the Basque Country (UPV/EHU) \\ Avda. Lehenadakari Agirre 83, 48015 Bilbao (Spain)
}

\section{Accepted for publication in the Journal of Business Venturing}

Please cite as:

Arzubiaga, U., Kotlar, J., De Massis, A., Maseda, A., Iturralde, T. (2018). Entrepreneurial orientation and innovation in family SMEs: Unveiling the (actual) impact of the Board of Directors. Journal of Business Venturing, In press. DOI:

https://doi.org/10.1016/j.jbusvent.2018.03.002 


\title{
Entrepreneurial Orientation and Innovation in Family SMEs: Unveiling the (Actual) Impact of the Board of Directors
}

\author{
"Many family SMEs have a board of directors, but there is a big difference between having a board on paper \\ and having a truly functioning board" \\ John Davis, Founder and Chairman, Cambridge Family Enterprise Group
}

\begin{abstract}
Drawing on stewardship and resource dependence theories, we examine how the board of directors $(\mathrm{BoD})$ influences the link between entrepreneurial orientation $(\mathrm{EO})$ and ambidextrous innovation in small and medium sized family firms (family SMEs). Our analysis of 230 Spanish family SMEs shows that family involvement in the BoD has a negative effect on their ability to turn EO into innovation. Moreover, we show that the BoD's strategic involvement in service and control tasks and the provision of knowledge and skills have positive effects, whereas the intensity of BoD activity has a surprisingly negative effect. These findings underscore that the effects of the BoD on the entrepreneurship-innovation link are more complex than previously thought, pointing to the important role of both $\mathrm{BoD}$ composition and $\mathrm{BoD}$ functioning for enabling innovation in family SMEs.
\end{abstract}

\section{Introduction}

To sustain performance and survive in highly dynamic and competitive environments, firms need not only the willingness to engage in entrepreneurship - that is, entrepreneurial orientation (EO) (Lumpkin and Dess, 1996; Wiklund, 1999) - but also the ability to translate this orientation into simultaneous exploratory and exploitative innovation activities - that is, ambidextrous innovation (Gupta et al., 2006; Kammerlander et al., 2015; Tushman and O’Reilly, 1996). Unfortunately, small and medium sized enterprises (SMEs) lack the slack resources and the complex hierarchical administrative systems that support EO and ambidextrous innovation in larger firms (e.g., Lubatkin et al., 2006; Wiklund and Shepherd, 2003). Moreover, most SMEs are owned and managed by family members (Westhead and Cowling, 1998) who pursue a variety of conflicting economic and non-economic goals (Kotlar and De Massis, 2013). Although the resource limitations and goal conflicts of family SMEs are widely acknowledged as sources of heterogeneity in entrepreneurship and innovation among family firms, the factors that help family SMEs address these trade-offs and successfully turn EO into actual innovation 
activities are still little understood (Eddleston et al., 2008; Lubatkin et al., 2006; Moss et al., 2014).

Our paper aims to contribute to this ongoing debate by focusing on the role of the Board of Directors (BoD). The BoD has been shown to affect both corporate entrepreneurship and innovation (e.g., Corbetta and Salvato, 2004; Eddleston et al., 2012; Zahra, 1996), but virtually no research to date has examined the factors that influence their links. Moreover, existing research provides very limited insights on the BoD in family SMEs. In these firms, the role of the BoD varies greatly, ranging from having a mere symbolic function to being actively involved in valuecreating activities, such as strategic decision-making and access to valuable resources (Huse, 2007; Westphal and Zajac, 1998). This view is corroborated by evidence that many family SMEs do not make full use of their board (Institute for Family Business, 2016), notwithstanding that family business consultants advocate that the board should not be "merely a 'rubber stamping' body" (PwC, 2016: p.22). Therefore, unveiling the actual activities of the BoD can add much to our understanding of heterogeneity in entrepreneurship and innovation among family SMEs, and clarify the inconsistent and sometimes paradoxical findings in existing research (e.g., Chrisman et al., 2015; Duran et al., 2016).

Building on stewardship and resource dependence theories, we develop a theoretical model explicating the variety of effects of the BoD on the link between EO and innovation in family SMEs. Stewardship theory emphasizes family directors' emotional attachment to their business, their high identification with the firm, and their altruism and motivation to make an effective contribution to the board (Filatotchev et al., 2007; Miller et al., 2008; Zattoni et al., 2015). These insights, combined with the observation that most BoDs in family SMEs are commonly dominated by family members (Corbetta and Salvato, 2004; Eddleston and Kellermanns, 2007), form our baseline hypothesis on the effect of $B o D$ composition, particularly family involvement in the BoD (Sciascia et al., 2013), on the link between EO and innovation in family SMEs. 
Resource dependence theory complements these insights, indicating resource provision as a main function of the BoD (Hillman and Dallziel, 2003), and suggesting that the BoD can play an important role in overcoming the resource constraints of family SMEs by providing access to skills, expertise, and networks (Bammens et al., 2011). Accordingly, we examine how BoD functioning - specifically the BoD's active involvement in strategic decision-making (Forbes and Milliken, 1999; Machold and Farquhar, 2013; Minichilli et al., 2009), the BoD's quality attributes (Zahra and Filatotchev, 2004), and working style (Gabrielsson and Winlund, 2000; Zattoni et al., 2015) - influences the link between EO and innovation in family SMEs.

We test these effects in a sample of 230 Spanish family SMEs, providing three main contributions to literature. First, the study contributes to research on family firm innovation by underscoring the important distinction between merely having a board "on paper" (as many family firms do) and having a board that actually provides a real contribution. To our best knowledge, this is the first paper that directly tackles this important question, advancing the scholarly debate at the intersection of entrepreneurship, innovation, and corporate governance research. Second, this study also contributes new insights to family SME literature by clarifying some of the distinctive aspects of their BoDs (Conger et al., 1998; Daily et al., 2003), demonstrating that stewardship and resource dependence theories provide a basis for more precise predictions on the impact of BoDs on value creation in these firms. Thus, this study advances a more complete understanding of how the BoD's contribution goes beyond structural aspects, highlighting the importance of the BoD's functioning for value creation in family SMEs. Third, this study provides new insights on the heterogeneity of entrepreneurship and innovative behavior among family firms by disentangling EO - the firm's inclination toward entrepreneurship - from the ability to develop actual innovation activities, and showing that the BoD's composition and functioning may facilitate or hamper translating the former into the latter. Thus, our study points to the important role of the BoD in relation to addressing the willingness-ability paradox in family 
firm innovation (Chrisman et al., 2015; Duran et al., 2016).

\section{Theoretical development and hypotheses}

\subsection{The role of the BoD for EO and innovative behavior in family SMEs}

Existing literature points to an important link between EO and innovative behavior (Dess and Lumpkin, 2005). EO is broadly conceptualized as the firm's inclination toward entrepreneurship (Covin and Wales, 2012). However, EO reflects how a firm operates rather than what it actually does (Lumpkin and Dess, 1996). For example, Kollmann and Stöckmann (2014) argue that EO represents a firm's direction in terms of progression and change, while innovative behaviors include both exploratory activities aimed at developing and commercializing completely new products and services and exploitative activities aimed at incrementally improving existing products and services (e.g., Gupta et al., 2006; Lubatkin et al., 2006). Prior research suggests that while the benefits of EO can only be realized through actual innovation activities, EO does not automatically develop into such activities (e.g., Lumpkin and Dess, 1996; Moreno and Casillas, 2008; Wiklund, 1999; Wiklund and Shepherd, 2003). On the other hand, the ability to simultaneously engage in exploratory and exploitative innovation activities, that is, ambidextrous innovation or ambidexterity (March, 1991; Tushman and O’Reilly, 1996), is consistently shown to lead to superior performance (e.g., Gupta et al., 2006).

Existing research shows that family firms have a higher EO than non-family firms but do not always benefit from it (e.g., Naldi et al., 2007; Schepers et al., 2014). For example, some studies suggest that the coexistence of economic and non-economic goals (Kotlar and De Massis, 2013) pose important trade-offs between exploratory and exploitative innovation in family firms (Patel and Chrisman, 2014). Furthermore, existing research points to the inherent resource constraints of smaller family firms (De Massis et al., 2018; Lubatkin et al., 2006), heightening competition for resources between exploratory and exploitative innovations (Moss et al., 2014; Raisch and Birkinshaw, 2008). For these reasons, family business scholars have increasingly recognized the 
heterogeneity in entrepreneurship and innovation among family firms. Most notably, Chrisman et al. (2015) highlight a willingness-ability paradox in family firms, such that their willingness to innovate may not correspond to their ability to do so. Similarly, other studies show a gap between innovation input and innovation output in family firms (e.g., Block, 2012; Duran et al., 2016). Thus, understanding the challenges family SMEs face in translating their EO into actual innovative behaviors and identifying the factors that help them do so may contribute to unveiling the sources of heterogeneity in family firm innovation behavior.

While scholars have considered numerous factors in the ongoing bid to identify those that drive variations in innovation among family firms (e.g., Lubatkin et al., 2006; Patel and Chrisman, 2014), the role of the BoD has been largely neglected. This is an important research gap given that the BoD can influence both corporate entrepreneurship and innovation in family firms (e.g., Corbetta and Salvato, 2004; Eddleston et al., 2012; Zahra, 1996). Although the BoD's role in bridging the entrepreneurship-innovation gap is acknowledged in general management literature (e.g., Baysinger et al., 1991), its role in family SMEs has not been empirically investigated to date. By disentangling the different dimensions of the $\mathrm{BoD}$ and examining how these may facilitate or hamper the translation of EO into actual innovation activities in family SMEs, we hope to provide new insights on the heterogeneity of entrepreneurship and innovative behaviors among family firms.

\subsection{BoDs in family SMEs}

The role of the BoD in family firms has been the subject of considerable debate (e.g., Anderson and Reeb, 2004; Bammens et al., 2011; Corbetta and Salvato, 2004). Although scholars generally agree that the $\mathrm{BoD}$ can help address the lack of resources and managerial expertise in family SMEs (Hillman and Dalziel, 2003; Forbes and Milliken, 1999; Voordeckers et al., 2007), literature on BoDs has paid much more attention to large, publicly-traded family firms than family SMEs (Bammens et al., 2011). Nonetheless, prior research suggests that BoDs in family SMEs 
have distinctive structures and behaviors compared to larger firms (e.g., Uhlaner et al., 2007), and hence the existing assumptions and predictions may not be directly applicable to family SMEs.

On the one hand, prior research on BoDs in family firms primarily relies on agency theory, focusing on goal conflicts between the firm's owners and managers, and the agency control mechanisms that can ameliorate such conflicts (Jensen and Meckling, 1976). Accordingly, this literature suggests that the BoD's main purpose is to re-align conflicting interests through tackling family entrenchment and ineffective management (Eddleston et al., 2012), mediating and resolving conflicts among family members (Voordeckers et al., 2007), and protecting the family's interests in the business (Bammens et al., 2008). While these issues are common in large family firms, traditional agency theory may not be fully applicable to understand the BoD's role in family SMEs, where owners and managers typically belong to the same family and are bound by altruism (Bammens et al., 2011).

On the other hand, several authors argue that stewardship theory can provide a basis for a better understanding of BoDs in family SMEs, since this theoretical perspective accommodates the assumption of compatible goals between owners and managers (Jaskiewicz and Klein, 2007), and emphasizes the significant attachment of family members to their business, which makes them likely to exhibit marked levels of stewardship (Miller et al., 2008). Moreover, the BoD can be central to overcoming the inherent limitations of family SMEs, such as resource constraints and the absence of the complex hierarchical administrative systems common in large, publiclytraded firms (Bammens et al., 2011; Lubatkin et al., 2006). For these reasons, some scholars suggest that BoDs in family SMEs are better understood from the combined lens of stewardship theory (Davis et al., 1997) and resource dependence theory (Hillman and Dalziel, 2003; Pfeffer and Salancik, 1978). In this combined perspective, the BoD is expected to play a critical role by providing access to valuable resources (Huse, 2007; Westphal and Zajac, 1998), such as essential expertise (Schulze et al., 2001) and networking (George et al., 2001), through the human and 
social capital that board directors bring with them (Boivie et al., 2016).

The combination of stewardship and resource dependence theories suggests that the potential contribution of the BoD in family SMEs may not always be fully realized (Gabrielsson et al., 2016; Gnan et al., 2015). In fact, the BoDs of family SMEs tend to be less regulated and more informal than those of larger, publicly traded-firms (Uhlaner et al., 2007), suggesting that the BoD may often have only a symbolic role (Institute for Family Business, 2016; PwC, 2016). Thus, we argue that the role of the BoD in family SMEs is likely to vary greatly, and such variation is likely to add significantly to our understanding of heterogeneity in innovation among family firms.

Accordingly, we focus on two main BoD dimensions to explicate the variety of its effects, namely, BoD composition and $B o D$ functioning (Figure 1). BoD composition relates to the proportion of family members involved in the $\mathrm{BoD}$ (family involvement in the BoD) (Sciascia et al., 2013), while BoD functioning refers to (1) the strategic involvement of the BoD, i.e., its active involvement in strategic decision-making (Forbes and Milliken, 1999; Machold and Farquhar, 2013; Minichilli et al., 2009), and (2) the BoD's working style, i.e., its provision of knowledge and skills, and the intensity of BoD activity (Gabrielsson and Winlund, 2000; Zattoni et al., 2015). By building on this critical distinction and examining how each of these dimensions influences the link between EO and ambidextrous innovation in family SMEs, we develop more nuanced hypotheses on the effects of the $\mathrm{BoD}$ on the EO-innovative behavior relationship.

\section{Insert Figure 1 about here}

\subsection{The effect of the BoD on the EO-innovative behavior link in family SMEs}

\subsubsection{The effect of $B o D$ composition: Family involvement in the $B o D$}

A crucial dimension of $\mathrm{BoD}$ composition in family firms relates to family involvement in the $\mathrm{BoD}$, that is the proportion of family members sitting on the $\mathrm{BoD}$ (Bammens et al., 2008). According to stewardship theory, family directors are motivated to make an effective contribution 
to the board, either because they are also the owners of the business (Zattoni et al., 2015) or because they have private/personal interests to do so (Johannisson and Huse, 2000). As such, family involvement in the BoD can result in increased identification with the firm (Filatotchev et al., 2007) as well as altruism that reinforces the willingness to improve the firm's competitive position (Sciascia et al., 2013). Therefore, a stewardship attitude may stimulate family directors to seek new entrepreneurial opportunities to ensure the continuity of the family firm's legacy. Furthermore, family involvement makes it easier for the $\mathrm{BoD}$ to understand the challenges that the family firm faces as well as its strengths and weaknesses, resources and capabilities (Gabrielsson et al., 2016). BoDs with high levels of family involvement may thus be more effective as a group, given that directors on these boards are more aware of each other's skills (Kearney et al., 2009), facilitating information exchange thanks to the mutual trust and respect among family directors (Westphal, 1999; Zattoni et al., 2015).

However, prior studies examining the composition of BoDs in family firms primarily focus on larger firms where the BoD includes both family and non-family directors (e.g., Anderson and Reeb, 2004). In family SMEs, by contrast, BoDs are characterized by a relatively high level of family involvement (Corbetta and Salvato, 2004), hence the BoD's limited ability to provide access to resources outside the family is likely to counterbalance the positive effects of stewardship associated with family involvement in the BoD. In this regard, the resource dependence perspective allows extending the stewardship theory arguments by emphasizing the BoD's critical role in providing the knowledge, skills, experience, reputation, and contacts that family SMEs often lack (Van den Heuvel et al., 2006). In other words, the BoD's contribution depends on the directors' human and social capital, or the "board capital" (Sciascia et al., 2013).

Thus, although family directors may have a stewardship orientation, the diversity in knowledge, skills, and experience is likely to be lower in BoDs characterized by high family involvement, since family members generally have a similar educational and work background 
(Bammens et al., 2011; Verbeke and Kano, 2012). The lack of different views and resources may limit the extent to which the $\mathrm{BoD}$ is able to identify and evaluate alternative options, which is critical to effectively designing and implementing entrepreneurial initiatives (Voordeckers et al., 2007). A high level of family involvement in the BoD does not only limit the board's human capital but also the board's social capital (Zahra et al., 2003), potentially restricting the variety and quality of contacts that board members have, and thereby limiting access to outside knowledge from diverse sources (Arregle et al., 2007). Finally, BoDs with a high proportion of family members may be more risk averse than boards with lower family involvement, since family directors are likely to refrain from putting their family's wealth at risk, thus pursuing more conservative business strategies (Claessens et al., 2002). Taken together, these arguments suggest the following hypothesis:

\section{H1. Family involvement in the BoD negatively moderates the relationship between $\mathrm{EO}$ and ambidextrous innovation in family SMEs.}

\subsubsection{The effect of BoD functioning: BoD strategic involvement and working style}

The combination of stewardship and resource dependence theories points to the value of going beyond BoD composition and studying the group processes underlying the BoD's contribution to strategic decision-making (e.g., Forbes and Milliken, 1999). Relatedly, prior corporate governance research suggests that BoD functioning - that is, involvement in strategic decisionmaking and working style - may have an important and complementary role to that of BoD composition.

The BoD's ability to influence the processing of strategic issues is based on its strategic involvement in service and control tasks (Forbes and Milliken, 1999; Huse, 2005; Machold and Farquhar, 2013; Minichilli et al., 2009), which provides a first step toward a more nuanced understanding of how the BoD can actually contribute to innovation in family SMEs. The BoD's service task is defined as the extent to which the BoD contributes to initiating strategic proposals and making decisions on key goals and long-term strategies (Minichilli et al., 2009; Van Ees et 
al., 2009). The BoD's control task instead captures how active the BoD is in implementing and monitoring strategic decisions (Machold et al., 2011).

On the one hand, the BoD's involvement in developing strategic goals and plans, or service tasks, is important for family SMEs, as it allows family directors who commonly dominate the BoD to provide access to industry-specific knowledge and it facilitates understanding the valuecreation potential of entrepreneurial opportunities (Eddleston et al., 2012), and consequently, translating EO into actual innovations. On the other hand, if the BoD is not involved in service tasks, firm managers will likely struggle to understand when family or business goals need to be prioritized and when innovations should be undertaken to leverage the firm's current resources or renew its competitive advantage (Patel and Chrisman, 2014). Thus, unless the BoD is actively involved in service tasks, it will be difficult for family SMEs to effectively combine the board members' knowledge, systematize and exploit accumulated knowledge, or leverage trusted social networks and information channels built over generations (Craig and Moores, 2006). This will, in turn, reduce the family SME's ability to turn EO into exploratory and exploitative innovation.

Likewise, family directors' involvement in control tasks is crucial to accessing firm-specific knowledge and facilitating top-down knowledge flows across the organizational hierarchy, thereby smoothing the translation of EO into specific innovative projects (Raisch and Birkinshaw, 2008). Moreover, when a family SME has high EO, the BoD can use its own firm-specific knowledge to help managers understand the risk-return implications of different innovation projects in relation to both family and business goals, which is likely crucial to attain ambidextrous innovation in family SMEs. Indeed, exploratory and exploitative innovations involve different levels of financial and business risks (Kollman and Stöckmann, 2014), and family firms tend to shift their focus between the two over time (Patel and Chrisman, 2014). Because BoDs in family SMEs are characterized by high levels of family involvement, they are in a favorable position to understand the diverse cognitive frameworks of family firm managers 
(Mitchell et al., 2003), and can thus best assist information processing as long as they are involved in control tasks. Accordingly, we suggest that the BoD's active involvement in control tasks is likely to help family SMEs transform the firm's EO into a balanced set of exploratory and exploitative innovation activities.

Taken together, these arguments suggest that the two components of BoD strategic involvement, namely, active involvement in service tasks and in control tasks, have a positive effect on the link between EO and ambidextrous innovation:

\section{H2. The strategic involvement of the BoD in service and control tasks positively moderates the relationship between EO and ambidextrous innovation in family SMEs.}

According to the stewardship and resource dependence perspectives, the extent to which the BoD can contribute to strategic decision-making processes also depends on the directors' ability to bring in knowledge, experiences, and competences (Minichilli et al., 2009). Thus, although the BoD of family SMEs is likely to be characterized by family directors' greater stewardship, resource dependence theory suggests that the directors' provision of knowledge and skills is crucial for BoDs to effectively fulfill their strategic tasks (Huse, 1995; Eddleston et al., 2010). On the one hand, directors may contribute to the strategic decision-making process with firm-specific knowledge, industry-specific knowledge, and wider perspectives (Bammens et al., 2011). On the other hand, due to the relatively low general management experience of managers in family SMEs, the board directors' general management knowledge is particularly important to achieve an effective strategic process (Forbes and Milliken, 1999). This may allow managers to continuously interact with board members and make decisions based on the directors' useful knowledge and expertise (Gabrielsson and Winlund, 2000).

However, although board directors are commonly regarded as highly competent professionals with important knowledge and skills (Minichilli et al., 2009; Eddleston et al., 2010), the mere presence of these factors among board members is not a sufficient condition to make real contributions to the board's tasks. Indeed, directors can effectively provide and integrate their 
expertise and skills for the benefit of group decisions only if the $\mathrm{BoD}$ actively provides access to its knowledge and skills during board meetings (Zattoni et al., 2015). Moreover, the active use of knowledge and skills requires coordinating the directors' contributions to allow their processing and availability in strategic decision processes (Forbes and Milliken, 1999). Indeed, resource dependence theory suggests that BoDs are information-processing structures whose success is based on the knowledge and expertise that directors share with other directors (Dalton and Dalton, 2011). Information sharing through the provision of knowledge and skills is likely to trigger “collective learning" among board members and raise awareness of the directors' competences and skills (Zattoni et al., 2015), which can enable higher group effectiveness (Jaskiewicz and Klein, 2007). This is likely to facilitate the development of group decision processes in the BoD, which may enrich not only strategic decision-making but also decisions on strategy implementation (Boivie et al., 2016). Conversely, low levels of BoD provision of knowledge and skills may hamper effective information sharing, which in turn may hinder the BoD's actual contribution to transforming EO into ambidextrous innovation. Thus, we hypothesize:

\section{H3. The BoD provision of knowledge and skills positively moderates the relationship between EO and ambidextrous innovation in family SMEs.}

Finally, the intensity of BoD activity - defined as the frequency and length of BoD meetings (Vafeas, 1999) - is often regarded as one of the most significant factors of the BoD's working style (Chou et al., 2013). Moreover, the frequency and length of BoD meetings may have potentially significant governance implications as this is an important factor in improving the BoD's effectiveness (Huse, 1995).

More frequent and longer board meetings foster opportunities for directors to exchange information, discuss, and decide on the main issues the firm faces (Pugliese and Wenstøp, 2007), suggesting that the frequency and length of $\mathrm{BoD}$ meetings is an important factor for BoDs to succeed in their strategic tasks. Board meetings should be held often enough to facilitate the BoD in obtaining continuous reports on the firm's different issues (Gabrielsson and Winlund, 2000). 
Indeed, the board needs substantial firm-specific information and knowledge to make adequate business plans to survive, which requires time (Rutherford and Buchholtz, 2007). This is especially relevant in the case of family SMEs, as their inherent resource limitations and time constraints often clash with the greater difficulty to evaluate the trade-offs between economic and non-economic goals in their strategic decision-making (De Massis et al., 2018; Kotlar et al., 2017), and hence more meetings are likely to be needed to brief board members. Thus, increasing the intensity of BoD activity can counterbalance the weakness of the BoD's periodical working pattern and its effect on information exchange (Pugliese and Wenstøp, 2007).

In addition, greater frequency and length of meetings may also be helpful for family directors who often dominate the BoD of family SMEs, as higher BoD activity intensity can increase objectivity and a long-term focus (Gabrielsson and Winlund, 2000). Higher intensity of BoD activity may also contribute to achieving high levels of social cohesion and trust among board members (Boivie et al., 2016). The lack of mutual knowledge, or knowledge that a group shares, can reduce the BoD's ability to share information and make timely and effective decisions (Hinds and Bailey, 2003). Moreover, BoDs that do not frequently meet often have greater difficulty in developing positive sentiment among board members and reducing potential conflicts (Vafeas, 1999). This may hinder trust among directors and render BoDs less cohesive (Boivie et al., 2016), which may result in less effective strategic decision-making. Likewise, the length of board meetings is likely to be a significant factor, as BoDs should have enough time to make effective decisions (Conger et al., 1998). Discussions about relevant choices, such as opportunity identification and strategy design, require that board meetings last enough time (Stiles, 2001). Formally stated:

H4. The intensity of BoD activity positively moderates the relationship between $\mathrm{EO}$ and ambidextrous innovation in family SMEs.

\section{Methodology}

\subsection{Data and sample}


Our empirical analysis focuses on Spanish family SMEs included in the SABI 2013 (Iberian Balance Sheet Analysis System) database, which provides access to information on 2,000,000 companies in Spain. We imposed restrictions to obtain a final sample consistent with our objectives and representative of the population. First, companies affected by special situations, such as insolvency, winding up, or liquidation, were excluded. Second, we restricted our sample to non-listed limited companies that have a legal obligation to establish a BoD. Finally, we limited our analysis to companies that have between 11 and 250 employees, resulting in a sample of 19,291 Spanish SMEs.

Following prior research (e.g., Westhead and Cowling, 1998), we identified family firms according to two conditions: (a) a family has ownership control when at least $50 \%$ of firm equity is in the family's hands, and (b) family members participate in firm management. Using the data available in the SABI database, we conducted a detailed examination of the shareholding structure (percentage of common stock) and the identity of owners and TMT members, focusing on their name and surname. The Spanish surname system allows identifying family relationships, including second-degree relationships (uncles, aunts, first cousins, and so on) based on surnames, since children take both their father's and mother's surnames. Furthermore, we checked the family firm status using the respondents' self-identification of their business as a family firm.

A professional research survey company collected the data to ensure high quality (e.g., Cruz and Nordqvist, 2012). Consistent with prior research (e.g., Kellermanns et al., 2008; Zahra, 2005), we opted for a single respondent survey to address the difficulties in gaining access to primary data on BoDs in private firms (e.g., Daily et al., 2003; Minichilli et al., 2009), which is common in research surveying key informants (Simon and Shrader, 2012). A letter was sent to the CEOs presenting our research and requesting their collaboration. The role of these individuals qualified them to comment on organization-wide phenomena, becoming key informants for our study (Green et al., 2008) thanks to their overall vision of firm strategy and the increasing tendency of 
being responsible for entrepreneurial behavior in family firms (Memili et al., 2010). Furthermore, CEOs are deemed familiar with the issues under study and are likely to be in a better position than other BoD members to report on these (Minichilli et al., 2009).

Starting from the initial sample of 1,710 Spanish family SMEs, we obtained 230 responses ( $13.45 \%$ of the sample). The response rate is consistent with previous research on privately held firms, including studies on private firms in Spain (e.g., Moreno and Casillas, 2008). Moreover, a review of prior work on EO and innovation in SMEs revealed that our sample size and response rate are in line with research published in leading entrepreneurship journals (e.g., Kammerlander et al., 2015; Kellermanns and Eddleston, 2006; Kollmann and Stöckmann, 2014). Although the sample size relative to the population rarely affects the accuracy of the sample (Bryman and Cramer, 2001), we ran additional analyses to ensure that response bias was not an issue. We tested for any non-response bias by comparing the answers of early versus late respondents. Based on the order in which completed surveys were received, we broke the total pool into two response waves, and no statistically significant differences were found. Therefore, non-response bias should not be a problem in our study.

\subsection{Measures}

The variables used in our analysis rest on previously validated instruments. The dependent and independent variables, except for family involvement in $\mathrm{BoD}$, are based on multiple-item constructs with all items measured through Likert-type scales. Specifically, instead of using the more typical 1-5 and 1-7 scales, we used 0-10 scales given that these are most commonly used in Spain in both academic and non-academic fields. However, Dawes (2008) concludes that "there is very little difference among the scale formats in terms of variation about the mean, skewness or kurtosis". The sample description is shown in Table 1. The average family SME has 97.72 employees and is 28.46 years old. Consistent with our a priori assumptions and prior literature, the information on $\mathrm{BoD}$ size and composition indicates that family SMEs in our sample have 
generally small BoDs (average size $=4.21$ ) strongly dominated by family members (average family member ratio in the $\mathrm{BoD}=81.37 \%$, meaning 3.43 family directors). Therefore, we can conclude that the structure of these BoDs is dominated by family members, consistent with our initial assumptions.

\section{Insert Table 1 about here}

\subsubsection{Entrepreneurial orientation}

The measure of family firm EO rested on the second-order construct of Covin and Slevin (1989). This second-order reflective construct includes three dimensions: innovativeness, proactiveness, and risk-taking. The respondents were offered two opposing sentences, rating their orientation on a 0-10 Likert-type scale (Moreno and Casillas, 2008). The time horizon for the questions was the last 5 years. A higher overall score on the EO scale indicates higher EO, while lower scores indicate a more conservative orientation (Green et al., 2008).

\subsubsection{Ambidextrous innovation}

Based on He and Wong's (2004) scale, we asked respondents to evaluate ambidextrous innovation in their firms based on the following eight items on an 11-point scale $(0=$ "completely disagree" to $10=$ "completely agree"): the objectives of innovation projects undertaken in the last 5 years were to (1) introduce a new generation of products, (2) extend the product range, (3) open up to new markets, (4) enter new technology fields, (5) improve existing product quality, (6) improve production flexibility, (7) reduce production cost, and (8) improve yield or reduce material consumption. Firms with a high level of ambidextrous innovation have high scores on this scale, while those with a low level of ambidextrous innovation have low scores.

\subsubsection{Family involvement in the $B o D$}

Family involvement in the $\mathrm{BoD}$ was measured as the proportion of family members on the board (family director ratio) (Bammens et al., 2008).

\subsubsection{Strategic involvement of the BoD in service and control tasks}


To assess the BoD's strategic involvement, we followed Machold et al.'s (2011) scale previously validated by Minichilli et al. (2009) where respondents were asked to evaluate such involvement in the last 5 years on an 11-point scale ( $0=$ "very low" to $10=$ "very high"). Specifically, we measured the degree of the BoD's involvement in terms of service tasks (i.e., actively initiating strategic proposals, making decisions on long-term strategies and main goals) and control tasks (i.e., implementing strategic decisions, controlling strategic decisions).

\subsubsection{BoD provision of knowledge and skills}

To measure the BoD provision of knowledge and skills we relied on a previously validated scale (Gabrielsson and Winlund, 2000) where respondents were asked to evaluate such provision on an 11-point scale ( $0=$ "very low" to $10=$ "very high"). Specifically, we measured to what extent the board provides: (1) overall competence in two relevant areas of expertise, (2) familiarity with company operations, and (3) familiarity with industry conditions.

\subsubsection{Intensity of BoD activity}

To assess the intensity of BoD activity we followed the scales of Gabrielsson and Winlund (2000). Specifically, respondents were asked the following two items: (1) how many board meetings they usually held per year, and (2) how long an ordinary board meeting usually lasts (hours).

\subsubsection{Control variables}

To ensure appropriate model specification and consider possible alternative explanations of variations in EO and ambidextrous innovation, several control variables were included based on the findings of prior studies (Green et al., 2008). First, we controlled for firm size, measured by number of employees, as larger firms may have more slack resources to engage in entrepreneurship (Kellermanns and Eddleston, 2006). We then controlled for firm age, measured as the number of years since founding, as younger firms may have limited experience and therefore greater entrepreneurship and innovation challenges (Stam and Elfring, 2008). We used 
$\log$ transformations of both firm size and firm age to adjust for skewness. We also controlled for family ownership, measured as firm equity in the family's hands, and whether the CEO was a family member using a dummy variable ( 1 for family member CEO, 0 for non-family member CEO). In addition, we included as control variables BoD size, since family influence is stronger in smaller BoDs (Jaskiewicz and Klein, 2007), and the overlap between TMT and BoD members. We also included a control variable for BoD preparation and commitment, measured according to Gabrielsson and Winlund's (2000) scale. Specifically, respondents were asked to evaluate on an eleven-point scale $(0=$ "very low" to $10=$ "very high") the extent to which the BoD provides (1) overall competence in relevant areas of expertise, (2) familiarity with company operations, and (3) familiarity with industry conditions. We then controlled for generation in control, as family firms managed by later generations are usually regarded as less innovative (Cruz and Nordqvist, 2012). Finally, to take potential sectorial influences into account (De Massis et al., 2018; Kammerlander et al., 2015), we classified all firms into one of five industry categories based on the two-digit SIC codes reported in the SABI database. Four categorical variables, coded 1-0, were created to denote steel, food, chemistry, electric industries; the automotive industry was used as the default group, and thus not included in the analyses.

\subsection{Analytical techniques}

Since this study relies on CEOs as keys respondents and on information provided by one person in a single timeframe (Campbell and Fiske, 1959), the results may be threatened by common method bias. To reduce these concerns, we ran two post hoc tests for common methods bias. Harman's single-factor test (Harman, 1967) showed that the first factor only accounted for $27.4 \%$ of total variance in the sample, while the remaining four factors accounted for $55.3 \%$ of variance (Kortmann, 2014). Moreover, following the procedure of Podsakoff et al. (2003), we included a common method factor linked to all the single-indicator constructs converted from the observed indicators. Thereafter, we compared the indicator variances explained by the method 
factor with the variance explained by the substantive constructs. On average, the constructs explained $67.95 \%$ of variance in the sample, whereas the method factor, on average, explained $0.73 \%$ of variance, resulting in a ratio of substantive variance to method variance of about 93.08 . In addition, most method factor loadings were not significant. Given that both tests, i.e., Harman's single-factor test and the inclusion of a method factor, did not indicate common method bias, we can contend that common method bias is either absent or negligible in our data (Kortmann, 2014).

To test our hypotheses, we used structural equation modeling, considered an appropriate analytic method to examine theoretical models with latent constructs (Fornell and Bookstein, 1982; Hair et al., 2012). Specifically, we used partial least squares (PLS) based on the features that have led to the increasing use of this technique in management and strategy research (e.g., Moreno and Casillas, 2008; Thai and Turkina, 2014). First, PLS can capture the normative implications of the total system of variables, and holistically clarify the entire model, which is relevant in our case as we estimate a model of simultaneous relationships and aim to have a complete overview of the impact of the BoD on EO and ambidextrous innovation. Second, PLSSEM works better when analyzing predictive research models in the early stages of theory development (Moreno and Casillas, 2008) compared to covariance-based structural equation modeling (Fornell and Bookstein, 1982), and thus fits well with our research.

We used the SmartPLS 2.0 M3 Software to estimate our model (Ringle et al., 2005). The significance of PLS estimates is usually tested using the bootstrap method (Hair et al., 2012; Ringle et al., 2005). To estimate whether the relationships in our model are statistically significant, we constructed bootstrap percentile confidence intervals. Each bootstrap sample contains the same number of observations as the original sample, whereas the number of bootstrap samples was set equal to 5000 (Hair et al., 2012). Furthermore, we allowed for individual sign changes in the bootstrap procedure (Hair et al., 2012).

\section{Results}




\subsection{Measurement model and structural model assessment}

Before estimating the quality of the structural model, we assessed the reliability and validity of our measurement model ${ }^{1}$. Construct reliability, assessed with Cronbach's alpha (range .70 to .96 ), and composite reliability (range .83 to .97 ) exceeded the recommended minimum of .70 (Fornell and Larcker, 1981). Thus, one item from BoD knowledge and skills provision, one from BoD activity intensity, and two from ambidextrous innovation were removed to allow for a better adjustment of the model. All indicators were significantly associated with their respective constructs $(\mathrm{p}<0.001)$. Convergent validity (AVE) exceeded the accepted minimum level of 0.50 in all cases (Hair et al., 2012). Since none of the loadings were lower than 0.4 , none had to be deleted. Finally, we estimated the discriminant validity by testing unidimensionality based on the cross loadings of indicators and the Fornell-Larcker criterion (Fornell and Larcker, 1981; Hair et al., 2012). All constructs showed sufficient levels of discriminant validity. Correlations among variables are shown in Table 2. Interestingly, we noted that family involvement in the $\mathrm{BoD}$ is negatively correlated with BoD size and the intensity of BoD activity, but positively correlated with BoD provision of knowledge and skills. These relationships are consistent with the assumptions underlying our hypotheses, but also point to further interesting patterns that we explore more explicitly in the post-hoc analysis.

\section{Insert Table 2 about here}

We tested the quality of the structural model by evaluating the predictive validity using the coefficient of determination in endogenous variables $\left(\mathrm{R}^{2}\right)$ (Chin, 1998), the regression coefficients' significance using the bootstrapping technique (Hair et al., 2012), and the StoneGeisser-Criterion $\left(\mathrm{Q}^{2}\right)$ using the blindfolding procedure with an omission distance of 7 (Tenenhaus et al., 2005). The value for $\mathrm{R}^{2}$ for ambidextrous innovation is strong $(0.364)$. Notwithstanding the weaker values, the cross-validated redundancy measures show that the

\footnotetext{
${ }^{1}$ The full results are available from the authors.
} 
theoretical/structural model has predictive relevance $\left(\mathrm{Q}^{2}>0\right)$ (Hair et al., 2012). For hypotheses testing, we assessed the sign and magnitude of path coefficients and their $\mathrm{t}$-values obtained by applying nonparametric bootstrapping, calculating the effect sizes and total effects (Chin, 1998). Figure 2 reports the PLS path coefficients and t-values.

\subsection{Hypotheses testing}

As Figure 2 shows, we tested a series of hypotheses from which we can conclude that the overall model is significant with a relatively high explanatory power $\left(\mathrm{R}^{2}=0.216\right)$. As expected, EO has a positive and significant influence on ambidextrous innovation (path $=0.346, \mathrm{t}=6.410$, $\mathrm{p}<0.001$ ), confirming our initial assumption. To some extent, this study confirms other innovation research finding entrepreneurial attitude to be a strong driver of innovative behavior (Kollmann and Stöckmann, 2014).

Concerning our moderating hypotheses, our empirical results indicate that family involvement in the BoD has a significant negative effect on the EO-ambidextrous innovation link (path = 0.127, $\mathrm{t}=7.031, \mathrm{p}<0.001$ ), supporting H1. The strategic involvement of the BoD in service and control tasks has a positive effect on the EO-ambidextrous innovation link (path $=0.292, \mathrm{t}=8.325$, $\mathrm{p}<0.001$ ), supporting $\mathrm{H} 2$. Our results also show that BoD knowledge and skills provision helps transform EO into ambidextrous innovation in family SMEs (path $=0.213, \mathrm{t}=6.162, \mathrm{p}<0.001$ ), supporting $\mathrm{H} 3$. Nevertheless, the results show that the intensity of $\mathrm{BoD}$ activity (path $=-0.182, \mathrm{t}$ $=9.919, \mathrm{p}<0.001)$ is detrimental to transforming EO into ambidextrous innovation, thus rejecting H4. The explanatory power of our model with the moderating effects increases significantly $\left(\mathrm{R}^{2}\right.$ $=0.364)$.

Concerning the control variables, firm age (path $=-0.170, t=2.147, p<0.05$ ), BoD size (path $=-0.194, \mathrm{t}=2.385, \mathrm{p}<0.05)$, and board members' preparation and commitment ( $\mathrm{path}=-0.131$, $\mathrm{t}=2.023, \mathrm{p}<0.05)$ have a negative influence on ambidextrous innovation. Nevertheless, according to our results, having a family CEOs is positively related to ambidextrous innovation 
$($ path $=0.132, \mathrm{t}=2.189, \mathrm{p}<0.05)$

\section{Insert Figure 2 about here}

\subsection{Robustness test}

Given that our empirical analysis is cross-sectional, we examined the robustness of our results by addressing potential endogeneity issues related to reverse causality. We followed the procedure of Gruber et al. (2010) with the aim of identifying causal relationships among our variables. In particular, we contacted the original respondents to obtain an update for the EO and ambidextrous innovation measures 24-26 months after our initial data collection and received responses from 97 of the original respondents (42.17\% response rate). For these firms, we ran separate path analyses using the EO and innovation variables obtained from the first $(\mathrm{t} 0)$ and second data collections $(\mathrm{t}+2)$. The direction and magnitude of the relationships between EO (t0) and ambidextrous innovation ( $\mathrm{t} 2)(\beta=0.509 ; \mathrm{t}=54.633)$ were consistent with the original results. Therefore, we conclude that reverse causality is not an issue in our study.

\subsection{Post-hoc analyses}

Our main analyses concerned the moderating effects of $\mathrm{BoD}$ composition (i.e., family involvement in the $\mathrm{BoD}$ ) and $\mathrm{BoD}$ functioning (i.e., strategic involvement of the $\mathrm{BoD}, \mathrm{BoD}$ provision of knowledge and skills, and intensity of BoD activity) on the relationship between EO and ambidextrous innovation. However, we noted some significant correlations between BoD composition and functioning, suggesting that the interactive effects of $\mathrm{BoD}$ composition and $\mathrm{BoD}$ functioning deserve further attention. Thus, in a post-hoc analysis we explored whether there were three-way interactions among $\mathrm{EO}, \mathrm{BoD}$ composition, and $\mathrm{BoD}$ functioning indicating their joint effects on ambidextrous innovation ${ }^{2}$. Following Henseler and Fassott's (2010) guidelines for multi-group simultaneous path analysis (see, for example, Calantone, Schmidt, and Benedetto, 1997; Nadkarni and Narayanan, 200), we divided our sample into two groups according to the

\footnotetext{
${ }^{2}$ The full results are available from the authors.
} 
level of family involvement in the $\mathrm{BoD}$, using the average value of 0.81 as the cut-off point. Then, we estimated our proposed model separately in each group of observations, interpreting statistically significant differences in path coefficients between subsamples as three-way interactive effects (Qureshi and Compeau, 2009).

Our results reveal interesting patterns that complement and enrich our understanding of the hypothesized relationships. First, we found that the interactive effect of EO and BoD strategic involvement on ambidextrous innovation (the path proposed in Hypothesis 2) is stronger when family involvement in the $\mathrm{BoD}$ is low $(\mathrm{Path}=0.450)$ than when family involvement in the $\mathrm{BoD}$ is high $($ Path $=0.229)$. The difference between the two path coefficients was $p<0.001$. Second, we did not find any significant difference concerning the interactive effect of $\mathrm{EO}$ and $\mathrm{BoD}$ provision of knowledge and skills (Hypothesis 3) across the two sub-samples. Finally, the interactive effect of EO and the intensity of $\mathrm{BoD}$ activity (Hypothesis 4) was negative when family involvement in the $\mathrm{BoD}$ is low (Path $=-0.280$ ), but positive when family involvement in the $\mathrm{BoD}$ is high $(\mathrm{Path}=0.193)$, with the difference between the two significant at $\mathrm{p}<0.001$.

\section{Discussion}

Our study sheds light on the important and complex role of the BoD in helping family SMEs turn their EO into actual innovations, which is critical to sustaining performance and surviving in increasingly dynamic competitive environments (Kollmann and Stöckmann, 2014). Compared to large and publicly-traded family firms, the BoDs of family SMEs are commonly dominated by family members, are less regulated, and often have a merely symbolic role (Institute for Family Business, 2016; PwC, 2016). Thus, to provide a deeper and more nuanced understanding of the role of BoDs for entrepreneurship and innovation in family SMEs, we expanded the traditional focus on $B o D$ composition to encompass a broader view of $B o D$ functioning, including BoD involvement in strategic decision-making and its working style.

Consistent with the stewardship and resource dependence perspectives, our study of 230 
Spanish family SMEs shows that BoD composition - that is, family involvement in the BoD hinders the transformation of EO into ambidextrous innovation. However, family SMEs are better able to turn EO into ambidextrous innovation when the $\mathrm{BoD}$ is strategically involved in service and control tasks, and actively provides valuable knowledge and skills to strategic decision-making processes. Contrary to our initial expectations, we also find that the intensity of BoD activity negatively affects the relationship between EO and ambidextrous innovation in family SMEs. Overall, these findings unveil the distinctive aspects of BoDs in family SMEs, underscoring the importance of considering structural as well as behavioral variables to fully understand the complexity of their impact on entrepreneurship and innovation. Remarkably, our findings highlight the critical difference between having a BoD with a merely symbolic role and a BoD actively involved in strategic decision-making. Thus, our study contributes novel insights to literature at the intersection of corporate governance, entrepreneurship, and innovation.

First, our study suggests that family involvement in the BoD hinders the ability of family SMEs to turn EO into innovations. This finding supports the combined insights of stewardship and resource dependence theories whereby high levels of family involvement in the BoD limit the availability of "board capital" (Sciascia et al., 2013) in family SMEs. More specifically, although BoDs with high family involvement may be characterized by greater stewardship, our results suggest that these BoDs also have lower diversity in terms of knowledge, skills, and experience (Bammens et al., 2011), and even lower levels of networking (Zahra et al., 2003), which limit their ability to transform entrepreneurial orientation into ambidextrous innovation. This finding suggests that family SMEs that form a BoD simply to comply with government mandates and limit the involvement of non-family members are unable to attain the potential benefits that the $\mathrm{BoD}$ is supposed to provide for entrepreneurship and innovation.

Second, one of the most important findings of our research is that the actual effects of the $\mathrm{BoD}$ in family SMEs goes beyond the structural variables, such as BoD composition. Rather, what 
matters is BoD functioning in terms of its strategic involvement and working style. In this respect, both BoD members' strategic tasks (service and control of the firm's strategic processes) and their provision of knowledge and skills increase family SMEs' ability to transform EO into actual ambidextrous innovation. These results support our arguments that the BoD's involvement in service tasks plays a crucial role, supporting managers in combining tacit and procedural knowledge, organizing and exploiting accumulated knowledge, and adding fruitful social networks (Craig and Moores, 2006), which in turn facilitates turning the proclivity toward entrepreneurship into actual innovation activities. Moreover, our results also suggest that BoD involvement in control tasks is highly relevant to attain ambidextrous innovation in family SMEs, as this helps managers comprehend the risk-return implications of different innovation initiatives (Raisch and Birkinshaw, 2008). Finally, our results show that the quality of the directors' knowledge, competences, and skills (Minichilli et al., 2009) is an important condition for family SMEs' ability to obtain innovation from EO. Taken together, these results point to the paramount importance for family SMEs to ensure that the BoD does not only have a symbolic role and is actively involved in strategy making in order to boost the firm's ability to turn EO into ambidextrous innovation.

In addition to the main results, our post-hoc analyses also revealed that the positive effect of BoD strategic involvement is not equally strong in all family SMEs, but it is contingent on the level of family involvement in the BoD. Although these results are exploratory in nature and should be taken with caution, they provide further support for our initial argument that family SMEs must ensure that family directors are actively involved in strategy making in order to facilitate turning the firm's EO into ambidextrous innovation. What is more, the strategic involvement of the $\mathrm{BoD}$ appears to be important for non-family directors as well, pointing to other benefits not initially considered in our theorizing. Specifically, the finding that the positive effect of BoD strategic involvement is even stronger when family involvement in the $\mathrm{BoD}$ is 
relatively lower resonates with prior research emphasizing the potential schisms and divides between family and non-family members in family firms, which reduce the quality of decision making (e.g., Patel and Cooper, 2014). Thus, these findings suggest that the BoD's strategic involvement can also ensure more equal participation of family and non-family members in family firms' strategic decision processes, which in turn can help family SMEs turn EO into ambidextrous innovation. Clearly, the variety of mechanisms underlying the role of BoD strategic involvement in family SMEs deserves further attention and more nuanced analysis in future research.

Third, our study reveals an unexpected negative effect of the intensity of BoD activity on the relationship between EO and ambidextrous innovation in family SMEs. Based on the stewardship and resource dependence perspectives, we originally outlined the potential positive impact of frequency and length of $\mathrm{BoD}$ meetings by emphasizing the potential positive effects on the availability of continuous information on strategic issues (Huse, 1995), on the objectivity and long-term focus of $\mathrm{BoD}$ members (Gabrielsson and Winlund, 2000), and on social cohesion and trust among board members (Boivie et al., 2016). However, these expected positive effects were not observed in our sample, suggesting that the benefits of intense BoD activity may be offsets by its costs. In this respect, our post-hoc analysis further revealed that our hypothesis is supported when family involvement in the $\mathrm{BoD}$ is higher, partially supporting our main argument that more intense BoD activity in these firms is important to facilitate information exchange among family directors and increase their objectivity and long-term focus. On the other hand, however, when more non-family members are involved in the BoD these benefits become less prominent, and the cost of incorporating diverse knowledge and perspectives into strategic decision-making processes increases to the point of making intense $\mathrm{BoD}$ activity counterproductive for turning $\mathrm{EO}$ into ambidextrous innovation. While interesting, these mixed results deserve further examination in future studies. 
Taken together, our findings and contributions have important implications for research and practice regarding the role of corporate governance for entrepreneurship and innovation in family SMEs. First, our study underscores the importance of the BoD in family SMEs, showing that its effects are stronger and more complex than previously thought, and can add much to our understanding of heterogeneity in innovation among family firms. Moreover, our study suggests that the combination of stewardship and resource dependence theories can provide a valuable basis for explicating such complexity. More specifically, our study suggests that dimensions of BoD functioning, such as its strategic involvement in service and control tasks, and the quality of knowledge and skills the BoD provides, as well as the intensity of its activity, are crucial factors for family SMEs to turn their entrepreneurial orientation into ambidextrous innovation. Relatedly, these findings suggest that the BoD has a key role in addressing the discrepancy between innovation inputs and outputs in family firms (Duran et al., 2016), and the paradox between their willingness to innovate and their ability to do so (Chrisman et al., 2015). Second, our study also underscores the limited applicability of existing insights on the role of BoDs, mainly developed in the context of large firms, to the case of family SMEs, pointing to the need for more nuanced insights on the distinctive aspects of BoDs in these firms (Conger et al., 1998; Daily et al., 2003). Relatedly, we demonstrate that the stewardship and resource dependence perspectives provide a basis for more precise predictions on the impact of BoDs on value creation in family SMEs, thus informing future research at the intersection of corporate governance, corporate entrepreneurship, and innovation (e.g., Phan et al., 2009).

\subsection{Limitations}

We acknowledge some limitations of our study that offer opportunities for further research. First, while relying on a single informant is relatively common in research surveying key informants (Simon and Shrader, 2012), this could be a limitation due to inferring firm-level behavior based on CEO responses (e.g., Cruz and Nordqvist, 2012). We also rely on subjective 
data on our key constructs, which may bias our results. However, CEOs' in-depth knowledge on decision-making and firm processes in SMEs, and the scarcity of objective data on these firms, would seem to legitimize the use of subjective data obtained from a single informant. In addition, no cause for concern arose in testing for common method bias (Kellermanns and Eddleston, 2006). Second, our study was conducted on family SMEs in Spain. As such, cultural factors may influence our findings. Although we do not expect the results to differ greatly between Spain and other Western settings, we invite researchers to replicate our study in other geographic contexts to determine the generalizability of our findings. Third, given that our findings are based on crosssectional data, drawing causal inferences requires caution. Although the results of our robustness test suggest that our data are not susceptible to reverse causality, future research using longitudinal data could extend our results to incorporate considerations on how changes in BoD composition and functioning over time dynamically affect EO and innovation in family SMEs. Fourth, as is common in corporate governance literature, our measures are based on the responses of CEOs instead of directors, as gaining access to data related to the functioning of BoDs is particularly difficult (Zattoni et al., 2015). Further, CEOs are mostly responsible for entrepreneurship and innovative behavior in family SMEs (Memili et al., 2010) and are thus in a better position than other BoD members to report on this matter (Minichilli et al., 2009).

\subsection{Directions for future research}

Amongst others, three future research directions emerge prominently on the role of the BoD in the process of turning EO into ambidextrous innovation. First, our analysis supports stewardship and resource dependence theories' portrayals of the role of the BoD in small and medium sized family firms, while it also challenges the traditional agency theory view according to which, in larger firms, the $\mathrm{BoD}$ is primarily concerned with resolving goal conflicts between the firm's owners and managers (e.g., Bammens et al., 2008). These results call for more contextual approaches to theorizing about BoDs in family and non-family firms. For example, 
Miller et al. (2013) show that agency and stewardship relationships vary not only depending on the context of ownership and management, but also on the size and administrative complexity of the firm. Accordingly, future research should take the opportunity to integrate findings across different contexts and build more cumulative research results. For example, future research is needed to assess whether and to what extend our findings extend to the $\mathrm{BoD}$ of non-family SMEs. More broadly, future research is encouraged to use more heterogeneous samples or meta-analytic techniques to simultaneously address how the effects of $\mathrm{BoD}$ composition and $\mathrm{BoD}$ functioning differ between family and non-family firms as well as between smaller and larger firms. In this respect, our post-hoc results suggest that the effects of $\mathrm{BoD}$ functioning on the link between $\mathrm{EO}$ and ambidextrous innovation may vary depending on the level of family involvement in the BoD. These results, although explorative, indicate the opportunity for future research to examine further the heterogeneous functions and contributions of the BoD in SMEs depending on both the degree and types of family involvement in the firm. Taken together, our results indicate the need for further research to address the heterogeneity of BoDs across different types of family and nonfamily firms in order to provide cumulative knowledge about their organizational consequences.

Second, future research could further investigate the effect of $\mathrm{BoD}$ members' gender. The inconclusive findings on the effect of female board representation on strategic decision-making (e.g., Terjesen et al., 2009) highlight the need for more research on this issue. In this regard, analyzing whether gender diversity may moderate the relationship between EO and innovative behavior appears a valuable extension of this study. Further, it would be especially interesting to conduct this study in countries where family SMEs are very traditional and reluctant to include women in high positions on the organizational ladder.

Third, future research is needed to examine the role of the BoD when transforming ambidextrous innovation into firm performance. Although the direct and indirect effects of the BoD on firm performance are outside the scope of this study, further studies could extend this 
research by examining how $\mathrm{BoD}$ composition and functioning moderate the relationships between ambidextrous innovation and firm performance. This future research avenue will likely shed light on how this important strategic decision-making body can help transform actual innovations into financial performance and firm growth.

\subsection{Implications for practice}

Our insights on the importance of BoD composition and functioning as moderators of the EOinnovation relationship offer significant and interesting managerial implications. Turning EO into innovative activities is an important and complex challenge for family SMEs, and our study shows that these firms can better succeed in doing so if they make more strategic use of their BoD. Rather than simply forming a BoD to comply with regulations and external expectations, our study encourages family SME owners and managers to think more strategically about the BoD's composition, strategic involvement, and working style, and more broadly, its valuecreating contribution. For example, BoDs dominated by family members may not be able to provide sufficiently diverse perspectives to turn EO into innovative behavior. Yet, family SMEs can achieve greater benefits from the $\mathrm{BoD}$ when involved in strategic processes and adding valuable knowledge and skills to such processes. At the same time, family SMEs should carefully consider the intensity of BoD activity, as this factor could have unexpected effects on the firm's ability to turn EO into ambidextrous innovation.

\section{References}

Anderson, R.C., Reeb, D.M., 2004. Board composition: Balancing family influence in S\&P 500 firms. Administrative Science Quarterly, 49(2), 209-237.

Arregle, J.L., Hitt, M.A., Sirmon, D.G., Very, P., 2007. The development of organizational social capital: Attributes of family firms. Journal of Management Studies, 44(1), 73-95.

Bammens, Y., Voordeckers, W., Van Gils, A., 2008. Boards of directors in family firms: a generational perspective. Small Business Economics, 31(2), 163-180.

Bammens, Y., Voordeckers, W., Van Gils, A., 2011. Boards of directors in family businesses: a literature review and research agenda. International Journal of Management Reviews, 13(2), 134-152. 
Baysinger, B.D., Kosnik, R.D., Turk, T.A., 1991. Effects of board and ownership structure on corporate R\&D strategy. Academy of Management Journal, 34, 205-214.

Block, J.H., 2012. R\&D investments in family and founder firms: An agency perspective. Journal of Business Venturing, 27(2), 248-265.

Boivie, S., Bednar, M.K., Aguilera, R.V., Andrus, J.L., 2016. Are boards designed to fail? The implausibility of effective board monitoring. Academy of Management Annals, 10(1), 319407.

Bryman, A., Cramer, D., 2001. Quantitative data analysis with SPSS release 10 for Windows. New York.

Calantone, R.J., Schmidt, J.B., \& Benedetto, C.A., 1997. New product activities and performance: the moderating role of environmental hostility. Journal of Product Innovation Management, 14(3), 179-189.

Campbell, D.T., Fiske, D.W., 1959. Convergent and discriminant validation by the multitraitmultimethod matrix. Psychological bulletin, 56(2), 81.

Chin, W.W., 1998. The partial least squares approach to structural equation modeling. In Marcoulides, G. (Ed), Modern Methods for Business Research. Lawrence Erlbaum, Hillsdale, NJ.

Chou, H.I., Chung, H., Yin, X., 2013. Attendance of board meetings and company performance: Evidence from Taiwan. Journal of Banking \& Finance, 37(11), 4157-4171.

Chrisman, J.J., Chua, J., De Massis, A., Frattini, F., Wright, M., 2015. The ability and willingness paradox in family firm innovation. The Journal of Product Innovation Management, 32(3), 310-318.

Claessens, S., Djankov, S., Fan, J.P., Lang, L.H., 2002. Disentangling the incentive and entrenchment effects of large shareholdings. The Journal of Finance, 57(6), 2741-2771.

Conger, J.A., Finegold, D., Lawler, E.E., 1998. Appraising boardroom performance. Harvard Business Review, 76, 136- 148.

Corbetta, G., Salvato, C.A., 2004. The board of directors in family firms: one size fits all? Family Business Review, 17, 119-131.

Covin, J.G., Slevin, D.P., 1989. Strategic management of small firms in hostile and benign environments. Strategic Management Journal, 10(1), 75-87.

Covin, J.G., Wales, W.J., 2012. The measurement of entrepreneurial orientation. Entrepreneurship Theory and Practice, 36(4), 677-702.

Craig, J.B., Moores, K., 2006. A 10-year longitudinal investigation of strategy, systems, and environment on innovation in family firms. Family Business Review, 19(1), 1-10.

Cruz, C., Nordqvist, M., 2012. Entrepreneurial orientation in family firms: a generational perspective. Small Business Economics, 38(1), 33-49.

Daily, C.M., Dalton, D.R., Cannella, A.A., 2003. Corporate governance: decades of dialogue and data. Academy of Management Review, 28(3), 371-382.

Dalton, D.R., Dalton, C.M., 2011. Integration of micro and macro studies in governance research: CEO duality, board composition, and financial performance. Journal of Management, 37(2), 404-411.

Davis, J.H., Schoorman, F.D., Donaldson, L., 1997. Toward a stewardship theory of management. Academy of Management Review, 22(1), 20-47.

Dawes, J., 2008. Do data characteristics change according to the number of scale points used?. International Journal of Market Research, 50(1), 61-104. 
De Massis, A., Audretsch, D., Uhlaner, L., Kammerlander, N., 2018. Innovation with limited resources: Management lessons from the German Mittelstand. Journal of Product Innovation Management, 35(1), 125-146.

De Massis, A., Kotlar, J., Mazzola, P., Minola, T., Sciascia, S., 2018. Conflicting selves: Family owners' multiple goals and self-control agency problems in private firms. Entrepreneurship Theory \& Practice, in press.

De Massis, A., Kotlar, J., Wright, M., \& Kellermanns, F.W., 2018. Sector-based entrepreneurial capabilities and the promise of sector studies in entrepreneurship. Entrepreneurship Theory \& Practice, 42(1), 3-23.

Dess, G.G., Lumpkin, G.T., 2005. The role of entrepreneurial orientation in stimulating effective corporate entrepreneurship. Academy of Management Executive, 19(1), 147-156.

Duran, P., Kammerlander, N., Van Essen, M., Zellweger, T., 2016. Doing more with less: Innovation input and output in family firms. Academy of Management Journal, 59(4), 12241264.

Eddleston, K.A., Chrisman, J.J., Steier, L.P., Chua, J.H., 2010. Governance and trust in family firms: An introduction. Entrepreneurship Theory and Practice, 34(6), 1043-1056.

Eddleston, K.A., Kellermanns, F.W., 2007. Destructive and productive family relationships: A stewardship theory perspective. Journal of Business Venturing, 22(4), 545-565.

Eddleston, K.A., Kellermanns, F.W., Sarathy, R., 2008. Resource configuration in family firms: linking resources, strategic planning and technological opportunities to performance. Journal of Management Studies, 45(1), 26-50.

Eddleston, K.A., Kellermanns, F.W., Zellweger, T.M., 2012. Exploring the entrepreneurial behavior of family firms: does the stewardship perspective explain differences? Entrepreneurship Theory and Practice, 36(2), 347-367.

Filatotchev, I., Strange, R., Piesse, J., Lien, Y.C., 2007. FDI by firms from newly industrialised economies in emerging markets: corporate governance, entry mode and location. Journal of International Business Studies, 38(4), 556-572.

Forbes, D.P., Milliken, F.J., 1999. Cognition and corporate governance: Understanding boards of directors as strategic decision-making groups. Academy of Management Review 24(3), 489-505.

Fornell, C., Bookstein, F.L., 1982. Two structural equation models: LISREL and PLS applied to consumer exit-voice theory. Journal of Marketing Research, 19, 440-520.

Fornell, C., Larcker, D.F., 1981. Evaluating structural equation models with unobservable variables and measurement error. Journal of Marketing Research, 39-50.

Gabrielsson, J., Winlund, H., 2000. Boards of directors in small and medium-sized industrial firms: examining the effects of the board's working style on board task performance. Entrepreneurship and Regional Development, 12(4), 311-330.

Gabrielsson, J., Calabrò, A., Huse, M., 2016. Boards and value creation in family firms: an extended team production approach. In The handbook of board governance: a comprehensive guide for public, private and not-for-profit board members (ed. R. Leblanc), 748-763. John Wiley \& Sons Inc., Hoboken, NJ, USA.

George, G., Robley Wood, Jr. D., Khan, R., 2001. Networking strategy of boards: implications for small and medium-sized enterprises. Entrepreneurship and Regional Development, 13(3), 269-285. 
Gnan, L., Montemerlo, D. and Huse, M., 2015. Governance systems in family SMEs: the substitution effects between family councils and corporate governance mechanisms. Journal of Small Business Management, 53(2), 355-381.

Green, K.M., Covin, J.G., Slevin, D.P., 2008. Exploring the relationship between strategic reactiveness and entrepreneurial orientation: the role of structure-style-fit. Journal of Business Venturing, 23(3), 356-383.

Gruber, M., Heinemann, F., Brettel, M., Hungeling, S., 2010. Configurations of resources and capabilities and their performance implications: an exploratory study on technology ventures. Strategic Management Journal, 31(12), 1337-1356.

Gupta, A.K., Smith, K.G., Shalley, C.E., 2006. The interplay between exploration and exploitation. Academy of Management Journal, 49(4), 693-706.

Hair, J.F., Sarstedt, M., Ringle, C.M., Mena, J.A., 2012. An assessment of the use of partial least squares structural equation modeling in marketing research. Journal of the Academy of Marketing Science, 40, 414-433.

Henseler, J., Fassott, G., 2010. Testing moderating effects in PLS path models: an illustration of available procedures. In V. E. Vinzi, W. W. Chin, J. Henseler and H. Wang (eds), handbook of partial least squares: concepts, methods and applications, pp. 713-736. Berlin: Springer.

Harman, H.H., 1967. Modern factor analysis. Chicago: University of Chicago.

He, Z., Wong, P., 2004. Exploration vs. exploitation: an empirical test of the ambidexterity hypothesis. Organization Science, 15(4), 481-494.

Hillman, A.J., Dalziel, T., 2003. Boards of directors and firm performance: integrating agency and resource dependence perspectives. Academy of Management Review, 28(3), 383-396.

Hinds, P.J., Bailey, D.E., 2003. Out of sight, out of sync: Understanding conflict in distributed teams. Organization Science, 14(6), 615-632.

Huse, M., 1995. Boards of directors in Europe: Scandinavian experiences. In Proceedings of the International Association for Business and Society, 6, 785-796.

Huse, M., 2005. Accountability and creating accountability: A framework for exploring behavioural perspectives of corporate governance. British Journal of Management, 16(1), 565-579.

Huse, M., 2007. Boards, governance and value creation: The human side of corporate governance. Cambridge University Press.

Institute for Family Business, 2016. Family business entrepreneurship, IFB Research Foundation Report. ISBN: 978-0-9551898-6-9.

Jaskiewicz, P., Klein, S., 2007. The impact of goal alignment on board composition and board size in family businesses. Journal of Business Research, 60(10), 1080-1089.

Jensen, M.C., Meckling, W.H., 1976. Theory of the firm: managerial behavior, agency costs and ownership structure. Journal of Financial Economics, 3(4), 305-360.

Johannisson, B., Huse, M., 2000. Recruiting outside board members in the small family business: An ideological challenge. Entrepreneurship \& Regional Development, 12(4), 353378.

Kammerlander, N., Burger, D., Fust, A., Fueglistaller, U., 2015. Exploration and exploitation in established small and medium-sized enterprises: the effect of CEOs' regulatory focus. Journal of Business Venturing, 30(4), 582-602. 
Kearney, E., Gebert, D., Voelpel, S., 2009. When and how diversity benefits teams: The importance of team members' need for cognition. Academy of Management Journal, 52(3), 581-598.

Kellermanns, F.W., Eddleston, K.A., 2006. Corporate entrepreneurship in family firms: a family perspective. Entrepreneurship Theory and Practice, 30(6), 809-830.

Kellermanns, F.W., Eddleston, K.A., Barnett, T., Pearson, A., 2008. An exploratory study of family member characteristics and involvement: effects on entrepreneurial behavior in the family firm. Family Business Review, 1(1), 1-14.

Kollmann, T., Stöckmann, C., 2014. Filling the entrepreneurial orientation-performance gap: the mediating effects of exploratory and exploitative innovations. Entrepreneurship Theory and Practice, 38(5), 1001-1026.

Kortmann, S., 2014. The mediating role of strategic orientations on the relationship between ambidexterity-oriented decisions and innovative ambidexterity. Journal of Product Innovation Management, 32(5), 666-684.

Kotlar J., De Massis A., 2013. Goal setting in family firms: Goal diversity, social interactions, and collective commitment to family-centered goals. Entrepreneurship Theory and Practice, 37(6), 1263-1288.

Kotlar, J., Signori, A., De Massis, A., Vismara, S., 2017. Financial wealth, socioemotional wealth and IPO underpricing in family firms: A two-stage gamble model. Academy of Management Journal, in press. DOI: 10.5465/amj.2016.0256.

Lubatkin, M.H., Simsek, Z., Ling, Y., Veiga, J.F., 2006. Ambidexterity and performance in small-to medium-sized firms: the pivotal role of top management team behavioral integration. Journal of Management, 32 (5), 646-672.

Lumpkin, G.T., Dess, G.G., 1996. Clarifying the entrepreneurial orientation construct and linking it to performance. Academy of Management Review, 21(1), 135-172.

Machold, S., Farquhar, S., 2013. Board task evolution: a longitudinal field study in the UK. Corporate Governance: An International Review, 21(2), 147-164.

Machold, S., Huse, M., Minichilli, A., Nordqvist, M., 2011. Board leadership and strategy involvement in small firms: a team production approach. Corporate Governance: An International Review, 19(4), 368-383.

Memili, E., Eddleston K.A., Kellermanns, F.W., Zellweger, T.M., Barnett, T., 2010. The critical path to family firm success through entrepreneurial risk taking and image. Journal of Family Business Strategy, 1, 200-209.

Miller, D., Breton-Miller, L., Scholnick, B., 2008. Stewardship vs. stagnation: An empirical comparison of small family and non-family businesses. Journal of Management Studies, 45(1), 51-78.

Miller, D., Minichilli, A., Corbetta, G., 2013. Is family leadership always beneficial? Strategic Management Journal, 34(5), 553-571.

Minichilli, A., Zattoni, A., Zona, F., 2009. Making boards effective: an empirical examination of board task performance. British Journal of Management, 20(1), 55-74.

Mitchell, R.K., Morse, E.A., Sharma, P., 2003. The transacting cognitions of nonfamily employees in the family businesses setting. Journal of Business Venturing, 18(4), 533-551.

Moreno, A.M., Casillas, J.C., 2008. Entrepreneurial orientation and growth of SMEs: a causal model. Entrepreneurship Theory and Practice, 32 (2), 507-528.

Moss, T.W., Payne, G.T., Moore, C.B., 2014. Strategic consistency of exploration and exploitation in family businesses. Family Business Review, 27(1), 51-71. 
Nadkarni, S., Narayanan, V.K., 2007. Strategic schemas, strategic flexibility, and firm performance: the moderating role of industry clockspeed. Strategic Management Journal, 28(3), 243-270.

Naldi, L., Nordqvist, M., Sjöberg, K., \& Wiklund, J., 2007. Entrepreneurial orientation, risk taking, and performance in family firms. Family Business Review, 20(1), 33-47.

Patel, P.C., Chrisman, J.J., 2014. Risk abatement as a strategy for R\&D investments in family firms. Strategic Management Journal, 35, 617-627.

Patel, P.C., Cooper, D., 2014. Structural power equality between family and non-family TMT members and the performance of family firms. Academy of Management Journal, 57(6), 1624-1649.

Pfeffer, J., Salancik, G., 1978. The external control of organizations: a resource dependence perspective. New York, NY: Harper \& Row.

Phan, P.H., Wright, M., Ucbasaran, D., Tan, W.L., 2009. Corporate entrepreneurship: Current research and future directions. Journal of Business Venturing, 24(3), 197-205.

Podsakoff, P.M., MacKenzie, S.B., Lee, J.Y., Podsakoff, N.P., 2003. Common method biases in behavioral research: a critical review of the literature and recommended remedies. Journal of Applied Psychology, 88(5), 879-891.

Pugliese, A., Wenstøp, P. Z., 2007. Board members' contribution to strategic decision-making in small firms. Journal of Management and Governance, 11(4), 383-404.

PwC, 2016. The 'missing middle': Bridging the strategy gap in family firms. Family Business Survey 2016, downloaded from http://www.pwc.com/gx/en/services/familybusiness/family-business-survey-2016.html.

Qureshi, I., Compeau, D., 2009. Assessing between-group differences in information systems research: A comparison of covariance-and component-based SEM. MIS Quarterly, 33(1), 197-214.

Raisch, S., Birkinshaw, J., 2008. Organizational ambidexterity: antecedents, outcomes, and moderators. Journal of Management, 34(3), 375-409.

Ringle, C.M., Wende, S., Will, A., 2005. SmartPLS 2.0. Hamburg: SmartPLS.

Rutherford, M.A., Buchholtz, A.K., 2007. Investigating the relationship between board characteristics and board information. Corporate Governance: An International Review, 15(4), 576-584.

Schepers, J., Voordeckers, W., Steijvers, T. and Laveren, E., 2014. The entrepreneurial orientation-performance relationship in private family firms: The moderating role of socioemotional wealth. Small Business Economics, 43(1), 39-55.

Schulze, W.S., Lubatkin, M.H., Dino, R.N., Buchholtz, A.K., 2001. Agency relationships in family firms: theory and evidence. Organization Science, 12(2), 99-116.

Sciascia, S., Mazzola, P., Chirico, F., 2013. Generational involvement in the top management team of family firms: exploring nonlinear effects on entrepreneurial orientation. Entrepreneurship Theory and Practice, 37(1), 69-85.

Simon, M., Shrader, R.C., 2012. Entrepreneurial actions and optimistic overconfidence: the role of motivated reasoning in new product introductions, Journal of Business Venturing, 27(3), 291-309.

Stam, W., Elfring, T., 2008. Entrepreneurial orientation and new venture performance: the moderating role of intra- and extra-industry social capital. Academy of Management Journal, 51(1), 97-111. 
Stiles, P., 2001. The impact of the board on strategy: An empirical examination. Journal of Management Studies, 38(5), 627-650.

Tenenhaus, M., Vinzi, V.E., Chatelin, Y.M., Lauro, C., 2005. PLS path modeling. Computational Statistics and Data Analysis, 48(1), 159-205.

Terjesen, S., Sealy, R., Singh, V., 2009. Women directors on corporate boards: A review and research agenda. Corporate Governance: An International Review, 17(3), 320-337.

Thai, M.T.T., Turkina, E., 2014. Macro-level determinants of formal entrepreneurship versus informal entrepreneurship. Journal of Business Venturing, 29(4), 490-510.

Tushman, M.L., O’Reilly I.I.I., C.A., 1996. Managing evolutionary and revolutionary change. California Management Review, 38(4), 8-28.

Uhlaner, L., Wright, M., Huse, M., 2007. Private firms and corporate governance: an integrated economic and management perspective. Small Business Economics, 29 (3), 225-241.

Vafeas, N., 1999. Board meeting frequency and firm performance. Journal of Financial Economics, 53(1), 113-142.

Van den Heuvel, J., Van Gils, A., Voordeckers, W., 2006. Board roles in small and mediumsized family businesses: Performance and importance. Corporate Governance: An International Review, 14(5), 467-485.

Van Ees, H., Gabrielsson, J., Huse, M., 2009. Toward a behavioral theory of boards and corporate governance. Corporate Governance: An International Review, 17(3), 307-319.

Verbeke, A., Kano, L., 2012. The transaction cost economics theory of the family firm: Familybased human asset specificity and the bifurcation bias. Entrepreneurship Theory and Practice, 36(6), 1183-1205.

Voordeckers, W., Van Gils, A., Van den Heuvel, J., 2007. Board composition in small and medium-sized family firms. Journal of Small Business Management, 45(1), 137-156.

Westhead P., Cowling M., 1998. Family firm research: The need for a methodological rethink. Entrepreneurship Theory and Practice, 23(1), 31-33.

Westphal, J.D., 1999. Collaboration in the boardroom: Behavioral and performance consequences of CEO-board social ties. Academy of Management Journal, 42(1), 7-24.

Westphal, J.D., Zajac, E.J., 1998. The symbolic management of stockholders: Corporate governance reforms and shareholder reactions. Administrative Science Quarterly, 127-153.

Wiklund, J., 1999. The sustainability of the entrepreneurial orientation-performance relationship. Entrepreneurship Theory and Practice, 24(1), 37-48.

Wiklund, J., Shepherd, D., 2003. Knowledge-based resources, entrepreneurial orientation, and the performance of small and medium-sized businesses. Strategic Management Journal, 24(13), 1307-1314.

Zahra, S.A., 1996. Governance, ownership, and corporate entrepreneurship: the moderating impact of industry technological opportunities. Academy of Management Journal, 39, 17131735.

Zahra, S.A., 2005. Entrepreneurial risk taking in family firms. Family Business Review 18(1), 23-40.

Zahra, S.A., Filatotchev, I., 2004. Governance of the entrepreneurial threshold firm: A knowledge-based perspective. Journal of Management Studies, 41(5), 885-897.

Zahra, S.A., Matherne, B.P., Carleton, J.M., 2003. Technological resource leveraging and the internationalisation of new ventures. Journal of International Entrepreneurship, 1(2), 163186. 
Zattoni, A., Gnan, L., Huse, M., 2015. Does family involvement influence firm performance? Exploring the mediating effects of board processes and tasks. Journal of Management, 41(4), 1214-1243. 
Table 1

Sample description

\begin{tabular}{|c|c|c|c|c|c|}
\hline \multicolumn{2}{|l|}{ Firm characteristics } & $\mathbf{N}=\mathbf{2 3 0}$ & $\%$ & Mean & SD \\
\hline \multirow{4}{*}{ Firm size (employees) } & Between 11-100 employees & 141 & 61 & \multirow{4}{*}{97.72} & \multirow{4}{*}{113.51} \\
\hline & Between 101-150 employees & 45 & 20 & & \\
\hline & Between 151-200 employees & 23 & 10 & & \\
\hline & Between 201-250 employees & 21 & 9 & & \\
\hline \multirow{4}{*}{ Firm age (years) } & More than 40 years & 36 & 16 & \multirow{4}{*}{28.46} & \multirow{4}{*}{14.81} \\
\hline & Between 26 and 40 years & 103 & 45 & & \\
\hline & Between 11 and 25 years & 83 & 36 & & \\
\hline & Less than 10 years & 8 & 3 & & \\
\hline \multirow{2}{*}{ Family / Non-family CEO } & Family CEO & 108 & 47 & \multirow{2}{*}{0.47} & \multirow{2}{*}{0.50} \\
\hline & Non-family CEO & 122 & 53 & & \\
\hline \multirow{5}{*}{ Board size (directors) } & Three directors & 118 & 52 & \multirow{5}{*}{4.21} & \multirow{5}{*}{1.85} \\
\hline & Four directors & 41 & 18 & & \\
\hline & Five directors & 30 & 13 & & \\
\hline & Six directors & 19 & 8 & & \\
\hline & More than six directors & 22 & 9 & & \\
\hline \multirow{4}{*}{$\begin{array}{l}\text { Family involvement in the BoD } \\
\text { (family director ratio) }\end{array}$} & Between $0-25 \%$ & 4 & 2 & \multirow{4}{*}{0.81} & \multirow{4}{*}{0.23} \\
\hline & Between $26-50 \%$ & 26 & 11 & & \\
\hline & Between 51-75\% & 48 & 21 & & \\
\hline & Between $76-100 \%$ & 152 & 66 & & \\
\hline \multirow{5}{*}{ Family Ownership } & Between $50-60 \%$ & 15 & 7 & \multirow{5}{*}{0.92} & \multirow{5}{*}{0.14} \\
\hline & Between $61-70 \%$ & 12 & 5 & & \\
\hline & Between $71-80 \%$ & 16 & 7 & & \\
\hline & Between $81-90 \%$ & 23 & 10 & & \\
\hline & Between 91-100\% & 164 & 71 & & \\
\hline
\end{tabular}


Table 2

Correlations

\begin{tabular}{|c|c|c|c|c|c|c|c|c|c|c|c|c|c|c|c|}
\hline & Variable & 1 & 2 & 3 & 4 & 5 & 6 & 7 & 8 & 9 & 10 & 11 & 12 & 13 & 14 \\
\hline 1 & Ambidextrous innovation & 1 & & & & & & & & & & & & & \\
\hline 2 & Board size & $-0.19^{*}$ & 1 & & & & & & & & & & & & \\
\hline 3 & Family CEO & $0.13 *$ & -0.02 & 1 & & & & & & & & & & & \\
\hline 4 & EO & $0.35^{* * *}$ & -0.00 & -0.08 & 1 & & & & & & & & & & \\
\hline 5 & $\begin{array}{l}\text { Family involvement in the } \\
\text { BoD }\end{array}$ & 0.07 & $-0.23 * *$ & 0.07 & 0.12 & 1 & & & & & & & & & \\
\hline 6 & Firm age & $-0.17 *$ & $0.24 * *$ & -0.10 & 0.05 & -0.02 & 1 & & & & & & & & \\
\hline 7 & Firm size & -0.09 & 0.08 & -0.08 & 0.09 & -0.10 & 0.05 & 1 & & & & & & & \\
\hline 8 & Intensity of BoD activity & -0.04 & $0.24 * *$ & -0.13 & 0.03 & $-0.41 * * *$ & 0.02 & 0.10 & 1 & & & & & & \\
\hline 9 & Innovativeness & $0.35 * * *$ & -0.04 & -0.01 & $0.81 * * *$ & 0.13 & 0.01 & 0.07 & 0.02 & 1 & & & & & \\
\hline 10 & BoD knowledge and skills & 0.11 & -0.12 & 0.01 & 0.06 & $0.56^{* * *}$ & -0.10 & -0.11 & $-0.19^{*}$ & 0.05 & 1 & & & & \\
\hline 11 & Family ownership & 0.02 & -0.05 & -0.06 & 0.11 & 0.07 & -0.03 & 0.03 & 0.01 & 0.07 & -0.02 & 1 & & & \\
\hline 12 & $\begin{array}{l}\text { Preparation and } \\
\text { commitment of board } \\
\text { members }\end{array}$ & $-0.13^{*}$ & -0.05 & -0.05 & 0.02 & $0.18 *$ & 0.00 & -0.08 & 0.04 & -0.02 & 0.13 & -0.03 & 1 & & \\
\hline 13 & Proactiveness & $0.32 * *$ & 0.07 & -0.05 & $0.83 * * *$ & 0.08 & 0.12 & 0.12 & 0.02 & $0.54 * * *$ & 0.07 & 0.09 & 0.04 & 1 & \\
\hline 14 & Risk taking & $0.19 *$ & -0.04 & -0.13 & $0.79 * * *$ & 0.08 & -0.02 & 0.03 & 0.04 & $0.43 * * *$ & 0.02 & 0.10 & 0.03 & $0.51 * * *$ & 1 \\
\hline 15 & $\begin{array}{l}\text { Strategic involvement of } \\
\text { BoD }\end{array}$ & $0.19 *$ & -0.04 & -0.00 & 0.17 & -0.00 & -0.10 & 0.03 & $0.27 * *$ & 0.08 & 0.00 & -0.01 & $0.33 * *$ & 0.13 & $0.19^{*}$ \\
\hline
\end{tabular}

$*_{\mathrm{p}}<.05 ; * * \mathrm{p}<.01 ; * * * \mathrm{p}<.001$ 




Fig. 1. Research model 


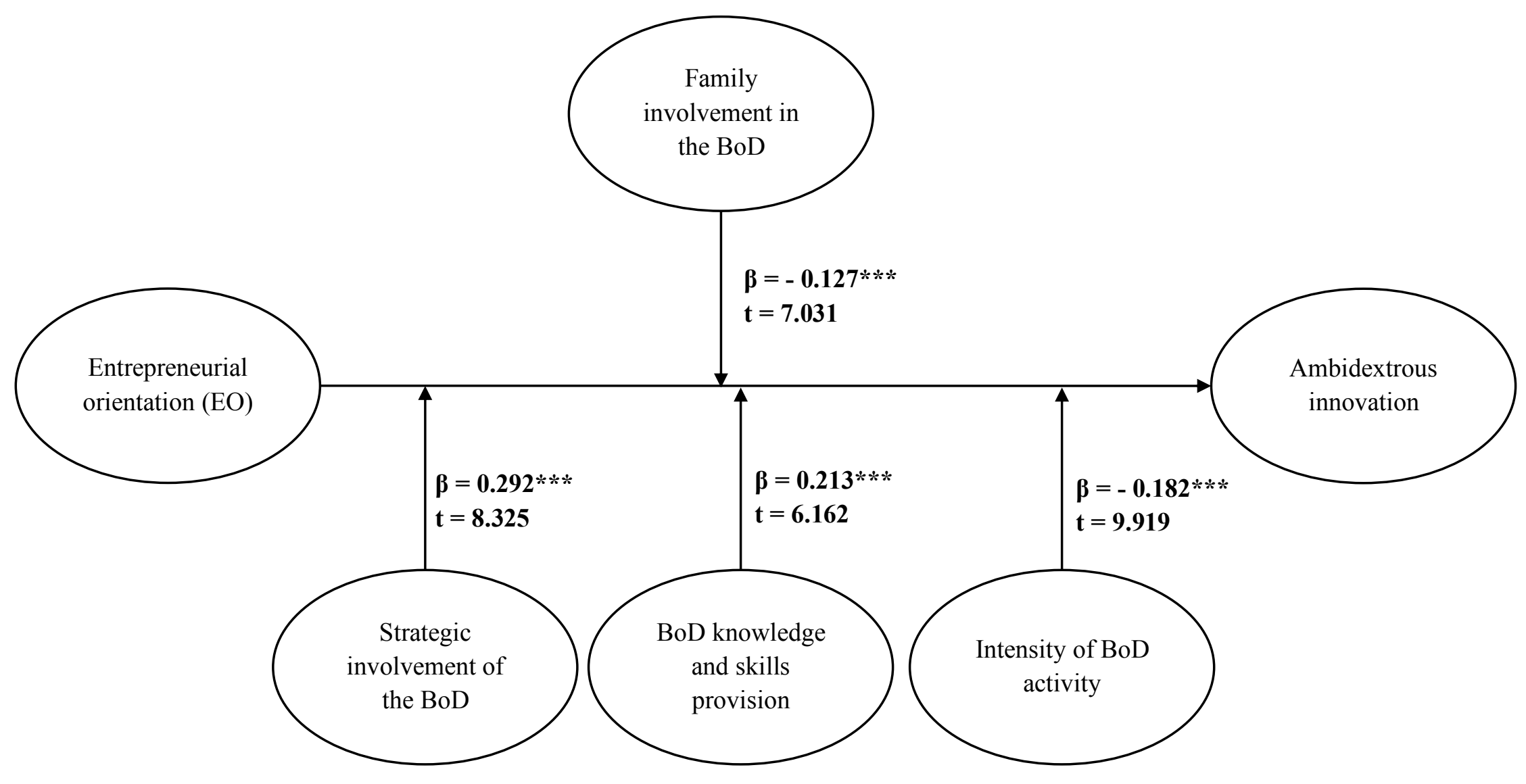

${ }^{*} \mathrm{p}<.05 ; * * \mathrm{p}<.01 ; * * * \mathrm{p}<.001$

Fig. 2. Hypotheses results 